\title{
Isolation and identification of lactic acid bacteria with probiotic potential from fermented flour of selected banana varieties grown in Sri Lanka
}

\author{
D.M.W.D. Divisekera ${ }^{1}$, J.K.R.R. Samarasekera ${ }^{1 *}$, C. Hettiarachchi ${ }^{2}$, J. Gooneratne ${ }^{1}$, M. Iqbal \\ Choudhary $^{3,4}$ and S. Gopalakrishnan ${ }^{5}$ \\ ${ }^{I}$ Industrial Technology Institute, 363, Bauddhaloka Mawatha, Colombo 07. \\ ${ }^{2}$ University of Colombo, 94, Kumaratunga Munidasa Mawatha, Colombo 07. \\ ${ }^{3}$ H.E.J. Research Institute of Chemistry, International Centre for Chemical and Biological Sciences, University of Karachi, Karachi, Sindh 75270, \\ Pakistan. \\ ${ }^{4}$ Dr Panjwani Center for Molecular Medicine and Drug Research, International Center for Chemical and Biological Sciences, University of \\ Karachi, Karachi, Sindh 75270, Pakistan. \\ ${ }_{5}^{5}$ International Crops Research Institute for the Semi-Arid Tropics, Patancheru, Hyderabad, Telangana 502324, India.
}

Submitted: 07 March 2018; Revised: 06 June 2018; Accepted: 20 July 2018

\begin{abstract}
This study aimed at isolating and identifying lactic acid bacteria (LAB) with probiotic potential from fermented flour of selected banana varieties grown in Sri Lanka and evaluating their probiotic and safety attributes in vitro. Ten lactic acid bacteria were isolated from six varieties of fermented banana flour, kolikuttu, seeni parakum, ambul nadee, ambum, seeni and anamalu. The isolates were screened for phenotypical and biochemical characteristics. The selected isolates were identified by $16 \mathrm{~S}$ rRNA sequencing as Enterococcus durans (two strains), E. gallinarum, E. hirae, E. faecium (two strains), Lactobacillus plantarum, L. curieae, Weissella cibaria and Pediococcus acidilactici and their partial sequences were deposited in NCBI. Among them, six isolates were selected based on the results of in vitro safety attributes and evaluated for their probiotic attributes. Three isolates, namely, E. durans MF405179.1, E. faecium MF574466.1 and L. curieae MF405178.1 isolated from kolikuttu, seeni parakum and ambul nadee, respectively demonstrated tolerance to acid, gastric juice, bile, salt, phenol and temperature under gastric conditions, and also showed susceptibility to tested antibiotics. Among the selected isolates, E. durans MF405179.1 demonstrated the highest hydrophobicity and auto-aggregation of $69.91 \%$ and $76.53 \%$, respectively. Further, it exhibited highest adhesion to both HCT116 and HT29 cell lines demonstrating $72.5 \%$ and $74.16 \%$ adhesion, respectively. This is the first report of isolation and characterisation of LAB
\end{abstract}

strains with probiotic potential from flour of banana varieties kolikuttu, seeni parakum, ambul nadee, ambum, seeni and anamalu grown in Sri Lanka.

Keywords: Fermented banana flour, lactic acid bacteria, probiotics.

\section{INTRODUCTION}

Probiotics are defined as 'live microorganisms, which when administered in adequate amounts confer health benefit to the host' (FAO/WHO, 2002). Prebiotics are non-digestible food components that are utilised by probiotics, which ultimately provide health benefits to the host (FAO, 2007). A positive relationship has been established between probiotic food and health benefits that include reduction of non-communicable diseases (such as hyperlipidemia, hypertension, colorectal cancers, kidney diseases and hepatic diseases), reduction of gastro intestinal diseases (such as irritable bowel syndrome, lactose intolerance, constipation, Helicobacter pylori infection and gastric ulcers), improved immunity, uro-genital health, oral health, metabolism and reduction of upper respiratory tract infections, sexually

*Corresponding author (radhika@iti.lk; (iD https://orcid.org/0000-0002-0480-5725)

This article is published under the Creative Commons CC-BY-ND License (http://creativecommons.org/licenses/by-nd/4.0/). This license permits use, distribution and reproduction, commercial and non-commercial, provided that the original work is properly cited and is not changed in anyway. 
transmitted diseases, allergies, inflammation reactions, neurological disorders and pregnancy and childhood associated disorders (Felley et al., 2001; Chmielewska \& Szajewska, 2010; Guglielmetti et al., 2011; Homayouni et al., 2012; Kechagia et al., 2013; Sharma \& Shukla, 2016). In order to exert beneficial effects to the host, potential probiotic candidates should possess a number of desirable characteristics, such as tolerance to gastric concentrations of acid, bile, salt, phenol, gastric juice and gastric temperature, ability to aggregate and adhere to epithelial cells and be free from virulence causing factors. These characteristics facilitate smooth transition of probiotics through the gut and enable colonisation (Gibson \& Fuller, 2000). Due to proven health benefits, probiotic foods have gained a high market revenue (Sharma et al.,2013) and is expected to reach 64.02 billion USD by 2022 (rnrmarketresearch.com). Majority of probiotic foods are of dairy origin, considering several known health risks associated with the consumption of dairy based probiotic foods, i.e. intolerance to milk sugar lactose, allergy to milk proteins, high fat and cholesterol content in the milk has led scientists to pursue alternative substrates to produce non-dairy probiotics (Kumar et al., 2015).

Banana (Musa species) is cultivated abundantly in tropical and subtropical regions and contributes to the economy of developing countries. Surprisingly, about one-fifth of the banana harvest is wasted and redundant (Rayo et al., 2015). In Sri Lanka, banana cultivation covers about $69-70 \%$ of the land area grown under fruits. At the Plant Genetic Resource Centre in Gannoruwa,
Sri Lanka, 29 banana cultivars and 2 wild species are preserved (Ekanayaka et al., 2011) including popular varieties such as seeni parakum, kandula, ambul nadee, nethrappalam, ambum, kolikuttu, seeni, anamalu and rathkesel. Besides being an abundant low-cost ingredient, banana flour is rich in prebiotics including dietary fibre components such as resistant starch, arabinoxylans and beta-glucans (Topping \& Clifton, 2001) and therefore is an ideal substrate for the non-dairy probiotic food industry. Several authors have successfully proved the compatibility of banana flour in food product development (Alves et al., 2016; Gomes et al., 2016; Segundo et al., 2017) including probiotic foods such as banana flour based probiotic drinks (Batista et al., 2017).

No studies have been reported to evaluate the flour of banana varieties grown in Sri Lanka as a potential probiotic and prebiotic source. With this background, the objective of this study was to isolate and identify lactic acid bacteria (LAB) with probiotic potential from fermented flour of selected banana varieties grown in Sri Lanka and evaluate the in vitro probiotic and safety attributes.

\section{METHODOLOGY}

\section{Sample collection, preparation and isolation of lactic acid bacteria}

Nine banana varieties were selected for the study (Figure 1). Five varieties, kolikuttu, ambul nadee,

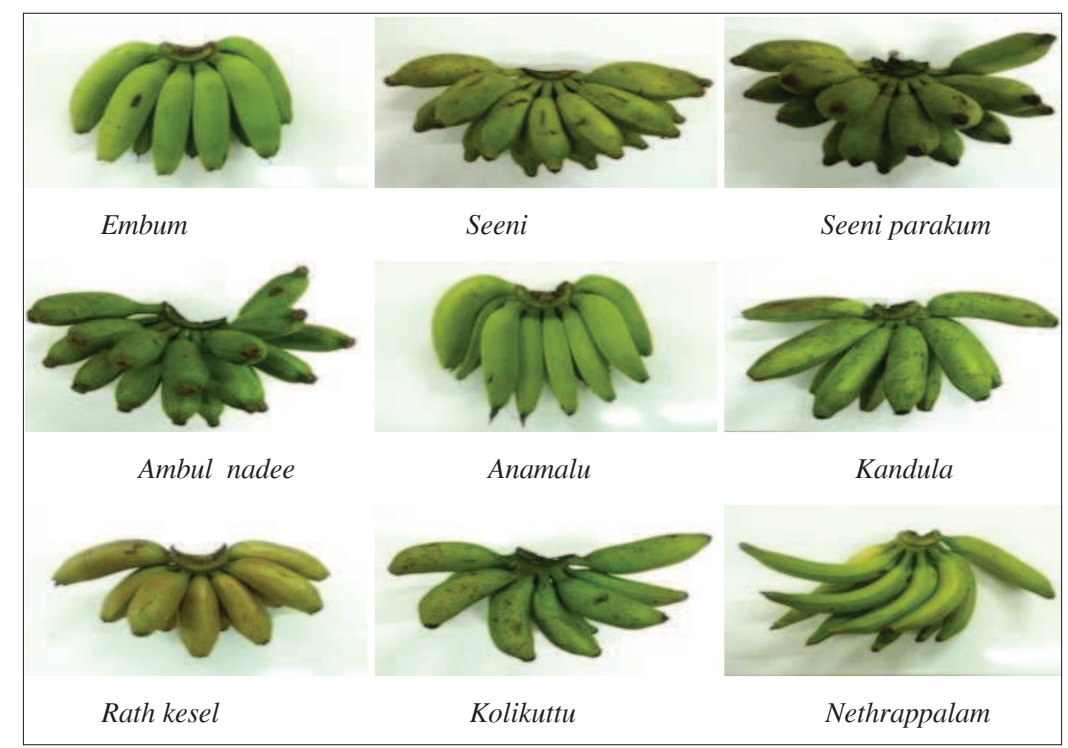

Figure 1: Banana varieties used in the study 
kandula, rath kesel and anamalu were collected from the Agriculture Research Centre, Girandurukotte, Sri Lanka. Three varieties; seeni, seeni parakum and nethrappalam were collected from the Agriculture Research Station, Thellijjawila, Sri Lanka. Ambum was collected from the Regional Agriculture Research and Development Centre, Angunakolapelessa, Sri Lanka. All banana varieties were grown in the first quarter of the year 2014 and the fruits were completely matured and green in colour at the time of harvesting. The fruits were transported to the Microbiology Laboratory, Industrial Technology Institute, Sri Lanka within $6 \mathrm{~h}$ at $<20 \pm$ $2{ }^{\circ} \mathrm{C}$. Peels of the fruits were removed, flesh was cut into $4 \mathrm{~mm}$ thick slices and soaked in $1 \%(\mathrm{w} / \mathrm{v})$ solution of sodium metabisulphite for $10 \mathrm{~min}$ to avoid enzymatic browning. Soaked banana pieces were dried in a tray dryer (JKO3RD KINKAI, China) at $35 \pm 2{ }^{\circ} \mathrm{C}$ till the moisture content reduced to $<10 \%$. The dried banana slices were ground in a variable speed rotor mill (Fritsch Pulverisette 14, Germany) and passed through a sieve $(0.5 \mathrm{~mm})$, packed in commercially sterile pouches and stored at $4{ }^{\circ} \mathrm{C}$. Twenty-five grams of flour of each variety of banana $(n=6)$ was transferred into pre-sterilised glass beakers covered with aluminum foil.

The flour samples were mixed with $100 \mathrm{~mL}$ of sterilised tap water and left to ferment in a biological safety cabinet at $26-28{ }^{\circ} \mathrm{C}$ for $18 \mathrm{~h}$. Each fermented sample was serially diluted up to $10^{6}$ in sterilised saline $(0.85 \% \mathrm{NaCl}, \mathrm{w} / \mathrm{v})$, spread on culture plates containing solidified De Man, Rogosa and Sharpe (MRS) agar (Oxoid, UK) (Reis et al., 2016) and incubated at $37{ }^{\circ} \mathrm{C}$ for $48 \mathrm{~h}$.

\section{Phenotypical and biochemical characterisation of lactic acid bacteria}

Culture plates were observed for colonies with typical LAB morphology and the isolated colonies were further streaked on fresh MRS agar at $37{ }^{\circ} \mathrm{C}$ to determine the purity. Colony morphology (form, size, shape, surface, texture, colour, elevation and margin) of the purified $\mathrm{LAB}$ isolates were evaluated as per the standard protocols (Kunchala et al., 2016). Phenotypical characterisation was performed using Gram staining, endospore staining (Collee et al., 2006) and motility evaluation (Pyar \& Peh, 2014). Biochemical tests including indole, methyl red, Voges Proskauer, citrate utilisation, catalase, oxidase, starch hydrolysis, urease, and amino acid hydrolysis (arginine, orinithine and lysine) were performed according to the methods given in Collee et al. (2006). Sugar fermentation pattern of LAB isolates were investigated according to Nazari et al. (2012) for sugars including glucose, fructose, maltose, lactose, galactose, melezitose, melibiose, arabinose, ribose, sucrose, salicin, sorbitol, mannitol, cellulose, cellobiose and dextrose (Sigma Aldrich, UK).

\section{Molecular identification of lactic acid bacteria}

Ten isolates that exhibited phenotypical and biochemical characteristics similar to $\mathrm{LAB}$ were selected for molecular identification. The selected LAB isolates were inoculated into MRS broth and incubated at $37^{\circ} \mathrm{C}$ for $18 \mathrm{~h}$. From each bacterium, $2 \mathrm{~mL}$ of centrifuged $\left(14000 \times \mathrm{g}\right.$ at $4{ }^{\circ} \mathrm{C}$ for $2 \mathrm{~min})$ pellet was mixed with Tris EDTA buffer $(200 \mu \mathrm{L})$ and re-centrifuged $\left(14000 \times \mathrm{g}\right.$ at $4{ }^{\circ} \mathrm{C}$ for $\left.2 \mathrm{~min}\right)$. This procedure was repeated once more. To each pellet, $10 \mu \mathrm{L}$ of proteinase $\mathrm{K}\left(100 \mu \mathrm{g} \mu \mathrm{L}^{-1}\right.$, w/v) was added and mixed well. Subsequently, sodium dodecyl sulfate (10\%, $10 \mu \mathrm{L}$ ) was added and incubated at $50{ }^{\circ} \mathrm{C}$ for $1 \mathrm{~h}$. After incubation, equal volumes of phenol and chloroform $(110 \mu \mathrm{L})$ were added and centrifuged $\left(14000 \times \mathrm{g}\right.$ at $4{ }^{\circ} \mathrm{C}$ for $2 \mathrm{~min})$. Ethanol $(30 \mu \mathrm{L}, \geq 99.8, \mathrm{v} / \mathrm{v})$ and sodium acetate $(15 \mu \mathrm{L}, 3 \mathrm{M})$ were added to the aqueous layer, mixed in a vortex mixture and incubated in an ice bath for $1 \mathrm{~h}$. After incubation, the tubes were centrifuged $(14000 \times \mathrm{g}$ at $4{ }^{\circ} \mathrm{C}$ for $\left.5 \mathrm{~min}\right)$. Subsequently, the pellets were mixed with ethanol ( $1 \mathrm{~mL}, 70 \%, \mathrm{v} / \mathrm{v})$ and centrifuged (14000 $\times \mathrm{g}$ at $4{ }^{\circ} \mathrm{C}$ for $\left.5 \mathrm{~min}\right)$. Supernatants were discarded and ethanol was evaporated. Finally, each pellet was dissolved in ultra pure PCR grade water $(40 \mu \mathrm{L})$ and stored at $-20{ }^{\circ} \mathrm{C}$ (Shahriar et al., 2011 modified). The extracted DNA was analysed for its quantity and purity using a gel documentation system (BIO RAD, UK) by mixing $5 \mu \mathrm{L}$ of DNA with $2 \mu \mathrm{L}$ of gel loading dye, and the gel was run at $60 \mathrm{~V}$ for $15 \mathrm{~min}$. PCR was performed using Dr. Max DNA Polymerase in a DNA Engine Tetrad 2 Peltier Thermal Cycler (BIO-RAD, UK) under the following conditions: initial denaturation $\left(95^{\circ} \mathrm{C}\right.$, $5 \mathrm{~min}$ ) followed by 35 cycles of denaturation $\left(95^{\circ} \mathrm{C}\right.$, $30 \mathrm{~s})$, annealing $\left(55^{\circ} \mathrm{C}, 30 \mathrm{~s}\right)$, elongation $\left(72{ }^{\circ} \mathrm{C}, 1 \mathrm{~min}\right)$, and final elongation $\left(72{ }^{\circ} \mathrm{C}, 10 \mathrm{~min}\right)$. The universal primers 27F (5'AGAGTTTGATCCTGGCTCAG3') and 1492R (5'GGTTACCTTGTTACGACTT3') were used in PCR (Doi et al., 2013) and PCR product purification was carried out using the multiscreen-PCR filter plate (Millipore, USA). The 16S ribosomal RNA gene of the purified DNA products was sequenced at Macrogen, South Korea. Sequence analysis was done using Bioedit sequence alignment editor 7.0.2 software (Ibis therapeutics, Carlsbad, CA). The database search for homologous sequences was performed by basic local alignment tool of the National Center for Biotechnology Information (NCBI, USA). Sequences with an identity of $99 \%$ or higher to those in the databases were allocated 
to the same species (Altschul et al., 1990). The partial sequences of $16 \mathrm{~S}$ rRNA gene of LAB isolates were deposited at NCBI, USA. Phylogenetic analyses were conducted according to neighbour-joining method (Saitou \& Nei, 1987) in MEGA7.

\section{In vitro safety attributes of lactic acid bacteria}

The LAB isolates were investigated for safety attributes including hemolysis, DNase and gelatin hydrolysis (in vitro). For the hemolysis test, blood agar was prepared by supplementing blood agar base (Hi media, India) with sheep blood $(5 \%, \mathrm{v} / \mathrm{v})$. For the gelatin hydrolysis test, tryptone neopeptone dextrose agar (TND) was prepared $(\mathrm{w} / \mathrm{v})$ using tryptone $(1.7 \%)$, peptone $(0.3 \%)$, dextrose $(0.25 \%), \mathrm{NaCl}(0.5 \%), \mathrm{K}_{2} \mathrm{HPO}_{4}(0.25 \%)$, agar $(1.5 \%)$ and gelatin-bacteriological $(0.4 \%)$. For the DNase test, DNase agar (Oxoid, UK) was prepared according to manufacturer's instructions. The enzyme activities were performed by inoculating the LAB isolates $\left(10^{5} \mathrm{cfumL}^{-1}\right)$ into the respective agar as described above and incubated at $37{ }^{\circ} \mathrm{C}$ for $48 \mathrm{~h}$ (Gupta \& Malik, 2007). Blood agar plates were observed for the presence of hemolysis zones $\beta, \alpha$ and $\gamma$. TND agar plates were saturated with ammonium sulfate and observed for clear zones around the inoculated area. DNase agar plates were observed for thick plaque of growth around the colonies. The controls used were Streptococcus pyogenes ATCC 19615 and Serratia marcescens ATCC 13880 for hemolysis and DNase/gelatin liquefaction assays, respectively.

Probiotic attributes of lactic acid bacteria exposed to in vitro gastric conditions (acid, bile, salt, phenol, gastric juice and temperature)

The isolated LAB strains that confirmed safety attributes were inoculated into tubes containing sterile MRS broth and incubated at $37 \pm 1{ }^{\circ} \mathrm{C}$ for $18 \mathrm{~h}$. After incubation, the tubes were centrifuged at $10,000 \times \mathrm{g}$ at $4{ }^{\circ} \mathrm{C}$ for $15 \mathrm{~min}$. Subsequently, the pellets were washed with sterile saline $(0.89 \mathrm{NaCl}, \mathrm{w} / \mathrm{v})$ and centrifuged at $10,000 \times \mathrm{g}$ at $4{ }^{\circ} \mathrm{C}$ for $15 \mathrm{~min}$. Each pellet was individually suspended in MRS broth and adjusted to 0.5 MacFarland turbidity standards $\left(1.5 \times 10^{8} \mathrm{cfumL}^{-1}\right)$. From each bacterial suspension $100 \mu \mathrm{L}$ was inoculated into MRS broth adjusted as per the gut conditions (in vitro) including $\mathrm{pH}(1.5,3$ and 4, v/v HCl and $\mathrm{pH} 7$ as control), bile concentrations $(0.2,0.5,1.0,1.5$, and $2.0 \%, \mathrm{w} / \mathrm{v}$, porcine bile), salt concentrations $(4,5,8$, and $12 \%, \mathrm{w} / \mathrm{v} \mathrm{NaCl})$, phenol concentrations $(0.1,0.2,0.3,0.4$, and $0.5 \% \mathrm{v} / \mathrm{v}$ phenol) and simulated gastric juice at $\mathrm{pH} 2\left(0.05 \mathrm{gL}^{-1}\right.$ porcine bile, $0.10 \mathrm{gL}^{-1}$ lysozyme, and $0.10 \mathrm{gL}^{-1}$ pepsin) according to the method given by Aswathy et al. (2008). All the attribute tests were performed in triplicate and repeated twice.

\section{Antibiotic susceptibility of lactic acid bacteria}

The LAB isolates that survive in gastric conditions were selected for investigating the susceptibility/ resistance to antibiotics. Agar disc diffusion method (CLSI, 2012) was performed to evaluate the antibiotic susceptibilities of LAB using commercially available antibiotic discs (Oxoid) cefotaxime $(15 \mu \mathrm{g})$, gentamycin $(10 \mu \mathrm{g})$, tetracycline $(30 \mu \mathrm{g})$, chloramphenicol (30 $\mu \mathrm{g})$, sulphamethoxazole $(25 \mu \mathrm{g})$, ciprofloxacin $(5 \mu \mathrm{g})$, amikacin $(30 \mu \mathrm{g})$, bacitracin $(52 \mu \mathrm{g})$, ampicillin $(10 \mu \mathrm{g})$, amoxicillin $(30 \mu \mathrm{g})$, cephalothin $(30 \mu \mathrm{g})$, vancomycin $(30 \mu \mathrm{g})$ and erythromycin $(30 \mu \mathrm{g})$. Cells were prepared as mentioned in the attribute tests. LAB cell pellets were adjusted to 0.5 MacFarland turbidity standards $\left(1.5 \times 10^{8} \mathrm{cfumL}^{-1}\right)$. From each bacterial suspension, $100 \mu \mathrm{L}$ was tested against respective antibiotics. The plates were incubated at $37 \pm 1{ }^{\circ} \mathrm{C}$ for $24 \mathrm{~h}$. The experiment was performed in triplicate and repeated twice.

\section{Auto-aggregation ability of lactic acid bacteria}

The LAB isolates that survive in gastric conditions were selected for investigating the auto-aggregation ability. Auto-aggregation of LAB strains was investigated in vitro according to the method of Kos et al. (2003) with some modifications.

Test isolates were inoculated into sterile MRS broth and incubated at $37 \pm 1{ }^{\circ} \mathrm{C}$ for $18 \mathrm{~h}$. After incubation, the tubes were centrifuged at $10,000 \times \mathrm{g}$ at $4^{\circ} \mathrm{C}, 15 \mathrm{~min}$. Subsequently, the pellets were washed with sterile saline $(0.89 \mathrm{NaCl}, \mathrm{w} / \mathrm{v})$ and re-centrifuged at $10,000 \times \mathrm{g}$ at $4{ }^{\circ} \mathrm{C}$ for $15 \mathrm{~min}$. Each pellet was individually suspended in MRS broth and adjusted to 0.5 MacFarland turbidity standards $\left(1.5 \times 10^{8}\right.$ cfumL $\left.^{-1}\right)$. The cell suspensions $\left(3 \mathrm{~mL}^{-1}\right)$ were mixed for $10 \mathrm{~s}$ and incubated at $37 \pm 1^{\circ} \mathrm{C}$ for $5 \mathrm{~h}$. At intervals of $0,1,2,3,4$ and $5 \mathrm{~h}, 200 \mu \mathrm{L}$ of the upper suspension of each reaction mixture was transferred to 96 well plates. Absorbance was measured at $\chi=620 \mathrm{~nm}$. The auto-aggregation percentage was expressed as a function of time using the following formula;

Auto-aggregation (\%) $=1-\frac{A_{t}}{A_{0}} \times 100$

$\mathrm{A}_{\mathrm{t}}$ (Absorbance at time $t=1,2,3,4 \mathrm{~h}$ ); $\mathrm{A}_{0}$ (absorbance at $\mathrm{t}=0$ ) 


\section{Cell surface hydrophobicity of lactic acid bacteria}

Cell surface hydrophobicity was measured according to the method given by Kos et al. (2003). LAB isolates were inoculated into sterile MRS broth and incubated at $37 \pm 1{ }^{\circ} \mathrm{C}$ for $18 \mathrm{~h}$. The cells were harvested by centrifugation (Centurion Scientific k3 series, UK) at $5000 \times \mathrm{g}$ at $4 \pm 1{ }^{\circ} \mathrm{C}$ for $15 \mathrm{~min}$. The pellets were washed twice with phosphate buffered saline (PBS). The cells were adjusted to $10^{8} \mathrm{cfumL}^{-1}$ and re-suspended in $\mathrm{KNO}_{3}$ solution (0.1 Moldm $^{-3}, \mathrm{pH}$ 6.2). The initial absorbance of cell suspensions was measured at $\chi=620 \mathrm{~nm}\left(\mathrm{~A}_{0}\right)$. Each LAB strain was investigated for adhesion with 3 solvents; xylene (non-polar solvent), ethyl acetate (non-polar and basic solvent) and chloroform (non-polar and acidic solvent). One milliliter of each solvent was added separately to $3 \mathrm{~mL}$ of each cell suspension and incubated for $10 \mathrm{~min}$ at $37 \pm 1^{\circ} \mathrm{C}$. The two phase system was mixed for $2 \mathrm{~min}$. After mixing, the reaction mixture was incubated at $37 \pm 1{ }^{\circ} \mathrm{C}, 20 \mathrm{~min}$. The aqueous phase was removed and absorbance was measured at $620 \mathrm{~nm}$. Controls (LAB cells $10^{8}$ cfumL $^{-1}$ suspended in $\mathrm{KNO}_{3}$ solution) were prepared without adding the solvents and were measured parallel to tests. The percentage of LAB cell adhesion to solvents was calculated using following formula;

$\operatorname{MATS}(\%)=1-\frac{\mathrm{A}_{1}}{\mathrm{~A}_{0}} \times 100$

$\mathrm{A}_{1}=$ Absorbance of aqueous layer; $\mathrm{A}_{0}=$ Absorbance of control

\section{Cell adhesion of lactic acid bacteria}

The ability of the selected LAB strains to adhere to two epithelial cell lines, namely, Homo sapiens colon colorectal adenocarcinoma ATCC HTB-38 (HT-29) and Homo sapiens colon colorectal carcinoma ATCC CCL-247 (HCT-116) in vitro was performed according to Duary et al. (2011) with modifications. The cell lines were obtained from the bio bank of the ICCBS, University of Karachi, Pakistan and maintained in Dulbecco's modified Eagles medium (DMEM) supplemented with $10 \%$ fetal bovine serum (v/v), $1 \%$ l-glutamine $(\mathrm{v} / \mathrm{v})$, $1 \%$ penicillin-streptomycin solution $(\mathrm{v} / \mathrm{v})$ and $7.5 \%$ $\mathrm{NaHCO}_{3}$. The medium was sterilised by filtration and stored at $4 \pm 1{ }^{\circ} \mathrm{C}$ until use. Monolayer of cell lines with $80 \%$ confluence was used in the study. LAB strains were grown in MRS broth and adjusted to 0.5 MacFarland turbidity standards $\left(1.5 \times 10^{8} \mathrm{cfumL}^{-1}\right)$ as described earlier. LAB cells were further serially diluted in tubes containing sterilised PBS and the cell concentration was adjusted to $1.5 \times 10^{2}$ cfumL $^{-1}$. From each cell line, $10^{6}$ cellsmL $\mathrm{sm}^{-1}$ in $0.5 \mathrm{~mL}$ of DMEM was placed in 6 well tissue culture plates and incubated at $37 \pm 1{ }^{\circ} \mathrm{C}$ for $24 \mathrm{~h}$ in $5 \% \mathrm{CO}_{2}$. The cell culture media flasks containing HT-29 and HCT-116 were discarded and new media were added every other day. After 14 days of incubation (14 days post confluence phase) mono-layers were washed twice with sterile PBS. One milliliter of LAB strain and $1 \mathrm{~mL}$ of DMEM media were added into the wells containing monolayers $(n=9)$. The plates were further incubated (Nuaire NU-8700E, USA) at $37 \pm 1{ }^{\circ} \mathrm{C}$ for $1 \mathrm{~h}$ in $5 \%$ $\mathrm{CO}_{2}$. After $1 \mathrm{~h}$, the monolayers were washed five times with sterile PBS, fixed with methanol and observed under the microscope (Optica B 500 i, Italy) at a magnification of $100 \times$. Subsequently, the attached LAB cells/well were counted and the adhesion ability was expressed as the percentage ratio of the LAB cells initially inoculated and the LAB cells remained attached after washing with PBS.

\section{Statistical analysis}

All experiments were conducted in triplicate and repeated twice. The mean and standard error of the data obtained from parallel experiments were calculated using Minitab 14. One-way ANOVA (unstacked) followed by multiple comparisons using tukey's family error rate was performed to analyse the data. Values $p<0.05$ were considered as significant.

\section{RESULTS AND DISCUSSION}

\section{Phenotypical characteristics of lactic acid bacteria}

A total of 150 bacteria were isolated from seven varieties of fermented banana flour, namely, ambul nadee (20), ambum (29), seeni parakum (26), kolikuttu (16), kandula (10), seeni (27) and anamalu (22). No bacteria were isolated from rathkesel and nethrappalam varieties. Among them, 99 bacterial colonies demonstrated to have typical LAB colony morphology on MRS agar as described by De Man et al. (1960) of which, 65 were Gram positive cocci/bacilli that are non-spore forming and non-motile organisms isolated from ambul nadee (7), ambum (8), kandula (13), seeni parakum (8), kolikuttu (7), seeni (9) and anamalu (13). LAB are usually Gram positive cocci or bacilli, non-spore forming and non-motile organisms, hence these new isolates were tentatively identified as LAB, based on the phenotypic characters exhibited.

\section{Biochemical characteristics of lactic acid bacteria}

Biochemical characterisation of the 65 tentatively identified LAB revealed that 10 isolates, namely, K08, K14, K16, SP13, SP25, SP26, AN18, AM22, S27 and 
A29 were negative for catalase, oxidase, indole, Voges Proskauer, methyl red, citrate utilisation and starch hydrolysis, and LAB isolates SP25 and K14, and AN18 and SP13 were positive for $\mathrm{H}_{2} \mathrm{~S}$ and urease, respectively. K16 isolate showed starch hydrolysis, while isolates K08, SP13, SP26 and AM22 hydrolysed arginine and orinithine. None of the LAB isolates hydrolysed lysine. LAB usually show negative reactions to some biochemical tests including indole, methyl red, Voges Proskauer, citrate utilisation, catalase and oxidase (Chowdhary et al., 2012). $\mathrm{H}_{2} \mathrm{~S}$ production protects the bacterial cells from oxidase stress and antibiotics (Kimura, 2014), while urease activity helps probiotic LAB strains to counteract acid stress during fermentation processes (Mora \& Arioli, 2014). Amino acid hydrolysis during growth provides energy to LAB for their metabolic activities during fermentation (Pessione \& Cirrincione 2016). Hence, these $10 \mathrm{LAB}$ isolates were selected for further studies.

\section{Sugar fermentation pattern of lactic acid bacteria}

LAB represents a group of microorganisms that are functionally related by their ability to produce lactic acid during fermentation. The ability to ferment different carbohydrates is one of the important characteristics that makes LAB ideal for fermentation. All 10 selected LAB isolates could ferment sugars including glucose, fructose,

Table 1: Summary of the carbohydrate fermentation pattern of isolated lactic acid bacteria

\begin{tabular}{llllllllllllllllll}
\hline LAB isolates & G & F & M & L & G & MZ & MB & A & R & SU & SA & SO & Mn & C & CB & D \\
\hline K08 & + & + & + & + & + & - & - & - & - & + & - & - & + & - & - & + \\
K14 & + & + & + & + & + & - & - & - & - & + & - & + & + & + & - & + \\
K16 & + & + & + & + & + & - & - & - & - & + & - & - & + & - & - & + \\
SP13 & + & + & + & + & + & - & - & - & - & + & - & + & + & - & - & + \\
SP25 & + & + & + & + & + & - & - & - & - & + & - & + & + & - & - & + \\
SP26 & + & + & + & + & + & - & - & - & - & + & - & + & + & - & - & + \\
AN18 & + & + & + & + & + & - & - & - & - & + & - & + & + & - & - & + \\
AM22 & + & + & + & + & + & - & - & - & - & + & - & - & + & + & - & + \\
S27 & + & + & + & + & + & - & - & - & - & + & - & + & + & - & - & + \\
A29 & + & + & + & + & + & - & - & - & - & + & - & - & + & - & - & +
\end{tabular}

The letters K, SP, AN, AM, S and A display lactic acid bacteria isolated from banana varieties kolikuttu, seeni parakum, ambul nadee, ambum, seeni and anamalu, respectively. (G) glucose; (F) fructose; (M) maltose; (L) lactose; (G) galactose; (MZ) melezitose; (MB) melibiose; (A) arabinose; (R) ribose; (SU) sucrose; (SA) salicin; (SO) sorbitol; (Mn) mannitol; (C) cellulose; (CB) cellobiose; (D) dextrose; (+) ferment; (-) do not ferment.

Table 2: Molecular identification of newly isolated lactic acid bacteria

\begin{tabular}{lll}
\hline LAB isolates & Genus /species identification & $\begin{array}{l}\text { NCBI gene } \\
\text { bank accession }\end{array}$ \\
\hline K08 & Enterococcus durans & MF405179.1 \\
K14 & Enterococcus gallinarum & MF480436.1 \\
K16 & Lactobacillus plantarum & MF405177.1 \\
SP13 & Weissella cibaria & MF480445.1 \\
SP25 & Enterococcus hirae & MF480429.1 \\
SP26 & Enterococcus faecium & MF574466.1 \\
AN18 & Lactobacillus curieae & MF405178.1 \\
AM22 & Enterococcus durans & MF480435.1 \\
S27 & Pediococcus acidilactici & MF480433.1 \\
A29 & Enterococcus faecium & MF480430.1 \\
\hline
\end{tabular}

The letters K, SP, AN, AM, S and A display lactic acid bacteria isolated from banana varieties kolikuttu, seeni parakum, ambul nadee, ambum, seeni and anamalu, respectively. maltose, lactose, galactose, sucrose and dextrose. LAB strains AM22 and K14 could also ferment cellulose, while LAB isolates such as AN18, A29, SP13, SP25, SP26, K14 and S27 were found to ferment sorbitol. Except isolate S27, all the other isolates fermented mannitol. None of the isolates could ferment melezitose, melibiose, arabinose, cellobiose and ribose (Table 1). Similar observations on sugar fermentation have been reported by Langston and Bouma (1960) on LAB, which was isolated from grass silage. All the LAB isolates were observed to be hetero-fermentative producing lactic acid and $\mathrm{CO}_{2}$.

\section{Molecular identification of newly isolated lactic acid bacteria}

The LAB were identified by comparing 16S rRNA partial sequences with those present in NCBI gene bank. 
Sequences showed 98 - $99 \%$ identity to the existing sequences, which was assigned to the same genus and species. The accession numbers obtained after depositing partial sequences in NCBI gene bank are presented in Table 2.

\section{Safety attributes of isolated lactic acid bacteria}

Out of the $10 \mathrm{LAB}$ strains isolated from fermented banana flour, six isolates, namely, K08, K16, SP26,

Table 3: Safety attributes of isolated lactic acid bacteria (in vitro)

\begin{tabular}{|c|c|c|c|}
\hline LAB isolates & $\begin{array}{c}\text { Hemolytic } \\
\text { activity }\end{array}$ & $\begin{array}{l}\text { DNase } \\
\text { activity }\end{array}$ & $\begin{array}{c}\text { Gelatin } \\
\text { hydrolysis }\end{array}$ \\
\hline K08 & $\gamma$ & negative & negative \\
\hline K14 & $\gamma$ & negative & positive \\
\hline K16 & $\gamma$ & negative & negative \\
\hline SP13 & $\gamma$ & negative & positive \\
\hline SP25 & $\alpha$ & negative & negative \\
\hline SP26 & $\gamma$ & negative & negative \\
\hline AN18 & $\gamma$ & negative & negative \\
\hline AM22 & $\gamma$ & negative & positive \\
\hline S27 & $\gamma$ & negative & negative \\
\hline A29 & $\gamma$ & negative & positive \\
\hline Streptococcus pyogene ${ }^{\mathrm{a}}$ & $\beta$ & negative & negative \\
\hline Serratia marcescens ${ }^{\mathrm{b}}$ & $\gamma$ & positive & positive \\
\hline
\end{tabular}

The letters K, SP, AN, AM, S and A display lactic acid bacteria isolated from banana varieties; kolikuttu, seeni parakum, ambul nadee, ambum, seeni and anamalu, respectively. $\alpha$ - partial lysis of the red cells in the media; $\beta$ - complete lysis of the red blood cells in the media; $\gamma$ - non hemolytic. $n=9$. ${ }^{\text {a }}$ Positive control of hemolysis; ${ }^{b}$ positive control of DNase and gelatin hydrolysis
AN18, AM22 and S27 were free from hemolysis, DNase and gelatin hydrolysis activity and possess safety attributes (Table 3). Hemolysis, DNase and gelatin hydrolysis activity contribute to the incidence of virulence in microorganisms; therefore ideal probiotic candidates should be free from these virulence factors (Halder et al., 2017).

\section{Probiotic attributes of lactic acid bacteria (in vitro)}

Six LAB isolates K08, K16, SP26, AN18, AM22 and S27 demonstrated significant differences $(\mathrm{p}<0.05)$ in their probiotic attributes. Except isolate AM22, others tolerate acid up to $\mathrm{pH} 1.5$ (Table 4). Probiotic bacteria need to survive passage through the stomach, where the $\mathrm{pH}$ can lie between 1.5-2.0 and further are required to stay viable for 4 hours or more before they move to the gastro-intestinal tract. Hence, the primary host factors that may affect commercial probiotics are the elevated levels of acidity in the proventriculus and ventriculus. Therefore, being tolerant to acidic conditions is an important criterion to be considered throughout the selection of potential probiotic isolates to assure their viability and functionality (Dunne et al., 2001; Bakari et al., 2011). The average concentration of bile salts in the small intestine is around $0.2-0.3 \%$, and may increase up to $2 \%(\mathrm{w} / \mathrm{v})$ depending upon the host physiology as well as the type and amount of food ingested (Bakari et al., 2011; Menconi et al., 2013). Healthy humans commonly have about $0.3 \%$ bile (Vicente et al., 2008) and hence commercial probiotic bacteria need to tolerate at least up to $0.3 \%$ bile (Dunne et al., 2001). Except isolate S27, all the isolates tolerated up to $1.5 \%$ bile. Isolates $\mathrm{K} 08$, SP27 and AN18 tolerated up to $2 \%$ bile (Table 5). All isolates grew at temperature between $30-42^{\circ} \mathrm{C}$ (Table 6).

Table 4: Acid tolerance of isolated lactic acid bacteria

\begin{tabular}{lcccc}
\hline LAB isolates & \multicolumn{4}{c}{ Survival of LAB in pH after 6 h (OD at 620 nm) } \\
& control & $\mathrm{pH} 4$ & $\mathrm{pH} \mathrm{3}$ & $\mathrm{pH} 1.5$ \\
\hline K08 & $1.94 \pm 0.01^{\mathrm{a}}$ & $1.53 \pm 0.03^{\mathrm{b}}$ & $0.88 \pm 0.06^{\mathrm{c}}$ & $0.35 \pm 0.02^{\mathrm{d}}$ \\
$\mathrm{K} 16$ & $1.87 \pm 0.03^{\mathrm{a}}$ & $1.60 \pm 0.04^{\mathrm{b}}$ & $0.87 \pm 0.02^{\mathrm{c}}$ & $0.37 \pm 0.03^{\mathrm{d}}$ \\
$\mathrm{SP} 26$ & $1.99 \pm 0.00^{\mathrm{a}}$ & $1.67 \pm 0.04^{\mathrm{b}}$ & $0.84 \pm 0.03^{\mathrm{c}}$ & $0.38 \pm 0.03^{\mathrm{d}}$ \\
$\mathrm{AN} 18$ & $1.88 \pm 0.00^{\mathrm{a}}$ & $1.92 \pm 0.01^{\mathrm{a}}$ & $1.61 \pm 0.05^{\mathrm{b}}$ & $0.59 \pm 0.03^{\mathrm{c}}$ \\
$\mathrm{AM} 22$ & $1.70 \pm 0.04^{\mathrm{a}}$ & $1.35 \pm 0.01^{\mathrm{b}}$ & $0.84 \pm 0.00^{\mathrm{c}}$ & $0.01 \pm 0.00^{\mathrm{d}}$ \\
$\mathrm{S} 27$ & $1.80 \pm 0.03^{\mathrm{a}}$ & $1.41 \pm 0.02^{\mathrm{b}}$ & $0.42 \pm 0.03^{\mathrm{c}}$ & $0.24 \pm 0.02^{\mathrm{d}}$ \\
\hline
\end{tabular}

Data is expressed as mean $\pm \mathrm{SEM}, \mathrm{n}=9$. Within a row mean values superscripted with different letters are significantly different $(\mathrm{p}<0.05)$. The letters $\mathrm{K}, \mathrm{SP}, \mathrm{AN}, \mathrm{AM}$ and $\mathrm{S}$ display lactic acid bacteria isolated from banana varieties kolikuttu, seeni parakum, ambul nadee, ambum and seeni, respectively. Control - MRS broth of pH 6 . 
Table 5: Bile tolerance of isolated lactic acid bacteria

\begin{tabular}{lcccccc}
\hline LAB isolates & \multicolumn{5}{c}{ Survival of LAB in bile after 6 hours (OD at 620 nm) } \\
& Control & $0.2 \%$ & $0.5 \%$ & $1.0 \%$ & $1.5 \%$ & $2.0 \%$ \\
\hline K08 & $1.94 \pm 0.01^{\mathrm{a}}$ & $1.65 \pm 0.01^{\mathrm{b}}$ & $1.45 \pm 0.00^{\mathrm{c}}$ & $1.15 \pm 0.02^{\mathrm{d}}$ & $0.74 \pm 0.01^{\mathrm{e}}$ & $0.48 \pm 0.00^{\mathrm{f}}$ \\
K16 & $1.87 \pm 0.03^{\mathrm{a}}$ & $1.46 \pm 0.01^{\mathrm{b}}$ & $1.27 \pm 0.00^{\mathrm{c}}$ & $0.96 \pm 0.02^{\mathrm{d}}$ & $0.26 \pm 0.02^{\mathrm{e}}$ & $0.09 \pm 0.00^{\mathrm{f}}$ \\
SP26 & $1.99 \pm 0.00^{\mathrm{a}}$ & $1.85 \pm 0.01^{\mathrm{b}}$ & $1.43 \pm 0.00^{\mathrm{c}}$ & $1.18 \pm 0.00^{\mathrm{d}}$ & $0.54 \pm 0.00^{\mathrm{e}}$ & $0.23 \pm 0.01^{\mathrm{f}}$ \\
AN18 & $1.88 \pm 0.00^{\mathrm{a}}$ & $1.52 \pm 0.01^{\mathrm{b}}$ & $1.17 \pm 0.01^{\mathrm{c}}$ & $0.65 \pm 0.01^{\mathrm{d}}$ & $0.34 \pm 0.01^{\mathrm{e}}$ & $0.12 \pm 0.00^{\mathrm{f}}$ \\
AM22 & $1.80 \pm 0.03^{\mathrm{a}}$ & $1.44 \pm 0.01^{\mathrm{b}}$ & $1.19 \pm 0.00^{\mathrm{c}}$ & $0.98 \pm 0.00^{\mathrm{d}}$ & $0.28 \pm 0.00^{\mathrm{e}}$ & $0.01 \pm 0.00^{\mathrm{f}}$ \\
S27 & $1.70 \pm 0.04^{\mathrm{a}}$ & $1.34 \pm 0.01^{\mathrm{b}}$ & $1.18 \pm 0.00^{\mathrm{c}}$ & $0.88 \pm 0.03^{\mathrm{d}}$ & $0.09 \pm 0.00^{\mathrm{e}}$ & $0.03 \pm 0.00^{\mathrm{f}}$ \\
\hline
\end{tabular}

Data is expressed as mean $\pm \mathrm{SEM}, \mathrm{n}=9$. Within a row mean values superscripted with different letters are significantly different $(\mathrm{p}<0.05)$. The letters $\mathrm{K}, \mathrm{SP}, \mathrm{AN}, \mathrm{AM}$ and $\mathrm{S}$ display lactic acid bacteria isolated from banana varieties kolikuttu, seeni parakum, ambul nadee, ambum, and, seeni respectively. Control-isolates in MRS broth without bile salts.

Table 6: Temperature tolerance of isolated lactic acid bacteria

\begin{tabular}{lccc}
\hline LAB isolates & \multicolumn{3}{c}{$\begin{array}{c}\text { Survival of LAB at different temperatures } \\
\text { after } 6 \text { hours }(\text { OD at } 620 \mathrm{~nm})\end{array}$} \\
& $30^{\circ} \mathrm{C}$ & $37^{\circ} \mathrm{C}$ & $42^{\circ} \mathrm{C}$ \\
\hline K08 & $1.46 \pm 0.01^{\mathrm{b}}$ & $1.74 \pm 0.03^{\mathrm{a}}$ & $1.25 \pm 0.00^{\mathrm{c}}$ \\
K16 & $1.54 \pm 0.01^{\mathrm{b}}$ & $1.79 \pm 0.01^{\mathrm{a}}$ & $1.22 \pm 0.01^{\mathrm{c}}$ \\
SP26 & $1.46 \pm 0.01^{\mathrm{b}}$ & $1.88 \pm 0.00^{\mathrm{a}}$ & $1.33 \pm 0.01^{\mathrm{c}}$ \\
AN18 & $1.38 \pm 0.01^{\mathrm{c}}$ & $1.52 \pm 0.01^{\mathrm{b}}$ & $1.83 \pm 0.04^{\mathrm{a}}$ \\
AM22 & $1.26 \pm 0.02^{\mathrm{c}}$ & $1.57 \pm 0.01^{\mathrm{a}}$ & $1.45 \pm 0.01^{\mathrm{b}}$ \\
S27 & $1.35 \pm 0.01^{\mathrm{c}}$ & $1.95 \pm 0.03^{\mathrm{a}}$ & $1.55 \pm 0.01^{\mathrm{b}}$ \\
\hline
\end{tabular}

Data is expressed as mean $\pm \mathrm{SEM}, \mathrm{n}=9$. Within a row mean values superscripted with different letters are significantly different $(\mathrm{p}<0.05)$. The letters K, SP, AN, AM and S display lactic acid bacteria isolated from banana varieties kolikuttu, seeni parakum, ambul nadee, ambum and seeni, respectively.
The ability to tolerate normal body temperature enables the probiotics to have an active metabolism in the gut. On the other hand, the ability to tolerate high temperature enables a better rate of growth as well as a high yield of lactic acid production during fermentation and reduces the contaminations in fermentation processes (Ibourahema et al., 2008). All isolates K08, K16, SP26, AN18, AM22 and S27 tolerated up to $12 \%$ salt, except isolate AM22, which could tolerate salt up to $8 \%$ (Table7). When LAB survive in $6.5 \% \mathrm{NaCl}$, they are considered as osmo-tolerant. This osmo-tolerant characteristic of LAB enables them to carry out metabolism and lactic acid production even in the presence of high concentrations of salts in the gut (Menconi et al., 2014).

Except isolate AM22, all the other LAB tolerated simulated gastric juice of $\mathrm{pH} 1.5$ (Table 8). The ability of

Table 7: Salt tolerance of isolated lactic acid bacteria

\begin{tabular}{lccccc}
\hline LAB isolates & \multicolumn{5}{c}{ Survival of LAB in NaCl after 6 hours (OD at 620 nm) } \\
& Control & $4 \%$ & $5 \%$ & $8 \%$ & $12 \%$ \\
\hline K08 & $1.96 \pm 0.01^{\mathrm{a}}$ & $1.57 \pm 0.01^{\mathrm{b}}$ & $1.36 \pm 0.03^{\mathrm{c}}$ & $1.17 \pm 0.01^{\mathrm{d}}$ & $0.37 \pm 0.01^{\mathrm{e}}$ \\
K16 & $1.99 \pm 0.00^{\mathrm{a}}$ & $1.80 \pm 0.04^{\mathrm{b}}$ & $1.65 \pm 0.01^{\mathrm{c}}$ & $1.49 \pm 0.01^{\mathrm{d}}$ & $1.28 \pm 0.01^{\mathrm{e}}$ \\
SP26 & $1.94 \pm 0.01^{\mathrm{a}}$ & $1.65 \pm 0.01^{\mathrm{b}}$ & $1.47 \pm 0.00^{\mathrm{c}}$ & $1.27 \pm 0.00^{\mathrm{d}}$ & $0.95 \pm 0.01^{\mathrm{e}}$ \\
AN18 & $1.88 \pm 0.01^{\mathrm{a}}$ & $1.47 \pm 0.01^{\mathrm{b}}$ & $1.27 \pm 0.01^{\mathrm{c}}$ & $0.88 \pm 0.00^{\mathrm{d}}$ & $0.65 \pm 0.01^{\mathrm{e}}$ \\
AM22 & $1.75 \pm 0.01^{\mathrm{a}}$ & $1.36 \pm 0.00^{\mathrm{b}}$ & $0.96 \pm 0.00^{\mathrm{c}}$ & $0.36 \pm 0.01^{\mathrm{d}}$ & $0.07 \pm 0.00^{\mathrm{e}}$ \\
S27 & $1.87 \pm 0.02^{\mathrm{a}}$ & $1.67 \pm 0.00^{\mathrm{b}}$ & $1.15 \pm 0.01^{\mathrm{c}}$ & $0.55 \pm 0.01^{\mathrm{d}}$ & $0.24 \pm 0.00^{\mathrm{e}}$ \\
\hline
\end{tabular}

Data is expressed as mean $\pm \mathrm{SEM}, \mathrm{n}=9$. Within a row mean values superscripted with different letters are significantly different $(\mathrm{p}<0.05)$. The letters $\mathrm{K}, \mathrm{SP}, \mathrm{AN}, \mathrm{AM}$ and $\mathrm{S}$ display lactic acid bacteria isolated from banana varieties kolikuttu, seeni parakum, ambul nadee, ambum and seeni, respectively. 
Table 8: Simulated gastric juice tolerance of isolated lactic acid bacteria

\begin{tabular}{lcc}
\hline LAB isolates & $\begin{array}{c}\text { Survival of LAB in simulated gastric juice } \\
\text { after } 6 \text { hours (OD at 620 nm) } \\
\text { Control }\end{array}$ & $\begin{array}{c}\text { Simulated gastric } \\
\text { juice of } \mathrm{pH} 1.5\end{array}$ \\
\hline K08 & $1.96 \pm 0.01$ & $0.31 \pm 0.00^{\mathrm{c}}$ \\
K16 & $1.99 \pm 0.00$ & $0.38 \pm 0.00^{\mathrm{b}}$ \\
SP26 & $1.94 \pm 0.01$ & $0.13 \pm 0.00^{\mathrm{d}}$ \\
AN18 & $1.88 \pm 0.01$ & $0.87 \pm 0.00^{\mathrm{a}}$ \\
AM22 & $1.75 \pm 0.01$ & $0.02 \pm 0.00^{\mathrm{e}}$ \\
S27 & $1.87 \pm 0.02$ & $0.37 \pm 0.00^{\mathrm{b}}$ \\
\hline
\end{tabular}

Data is expressed as mean $\pm \mathrm{SEM}, \mathrm{n}=6$. Within column mean values superscripted with different letters are significantly different $(p<0.05)$. The letters K, SP, AN, AM and S display lactic acid bacteria isolated from banana varieties kolikuttu, seeni parakum, ambul nadee, ambum and seeni, respectively. Control - LAB in MRS broth. potential probiotic strains to survive in the human gastric juice is the key indication that displays the ability of the strains to survive passage through the stomach (Shewale et al., 2014). Except isolates $\mathrm{K} 16$ and S27, others tolerated $0.4 \%$ phenol (Table 9). Phenols are formed in the intestines by gut bacteria that deaminate various aromatic amino acids delivered by the diet or produced by endogenous proteins. These phenol compounds can inhibit the growth of probiotic LAB. Therefore, phenol tolerance is essential for their survival in the gastrointestinal tract (Yadav et al., 2016). The results of this study indicated that not all desirable probiotic characteristics are present within a single isolate, where many isolates displayed varying but promising capabilities. LAB isolates E. durans (K08), E. faecium (SP26) and L. curieae (AN18) demonstrated superior probiotic attributes; hence were selected for further studies.

Table 9: Phenol tolerance of isolated lactic acid bacteria

\begin{tabular}{lcccccc}
\hline LAB isolates & \multicolumn{5}{c}{ Survival of LAB in phenol after 6 hours (OD at 620 nm) } \\
& Control & $0.1 \%$ & $0.2 \%$ & $0.3 \%$ & $0.4 \%$ & $0.5 \%$ \\
\hline K08 & $1.96 \pm 0.01^{\mathrm{a}}$ & $1.67 \pm 0.01^{\mathrm{b}}$ & $1.24 \pm 0.00^{\mathrm{c}}$ & $0.86 \pm 0.01^{\mathrm{d}}$ & $0.66 \pm 0.01^{\mathrm{e}}$ & $0.55 \pm 0.00^{\mathrm{f}}$ \\
K16 & $2.00 \pm 0.00^{\mathrm{a}}$ & $1.35 \pm 0.01^{\mathrm{b}}$ & $0.86 \pm 0.00^{\mathrm{c}}$ & $0.58 \pm 0.00^{\mathrm{d}}$ & $0.02 \pm 0.00^{\mathrm{e}}$ & $0.01 \pm 0.00^{\mathrm{e}, \mathrm{f}}$ \\
SP26 & $1.94 \pm 0.01^{\mathrm{a}}$ & $1.76 \pm 0.01^{\mathrm{b}}$ & $1.52 \pm 0.03^{\mathrm{c}}$ & $1.13 \pm 0.01^{\mathrm{d}}$ & $0.75 \pm 0.01^{\mathrm{e}}$ & $0.56 \pm 0.01^{\mathrm{f}}$ \\
AN18 & $1.87 \pm 0.01^{\mathrm{a}}$ & $1.53 \pm 0.01^{\mathrm{b}}$ & $1.37 \pm 0.00^{\mathrm{c}}$ & $0.97 \pm 0.01^{\mathrm{d}}$ & $0.56 \pm 0.01^{\mathrm{e}}$ & $0.33 \pm 0.01^{\mathrm{f}}$ \\
AM22 & $1.75 \pm 0.01^{\mathrm{a}}$ & $1.66 \pm 0.01^{\mathrm{b}}$ & $0.64 \pm 0.02^{\mathrm{c}}$ & $0.23 \pm 0.01^{\mathrm{d}}$ & $0.38 \pm 0.00^{\mathrm{e}}$ & $0.01 \pm 0.00^{\mathrm{f}}$ \\
S27 & $1.86 \pm 0.02^{\mathrm{a}}$ & $1.25 \pm 0.01^{\mathrm{b}}$ & $0.86 \pm 0.01^{\mathrm{c}}$ & $0.56 \pm 0.01^{\mathrm{d}}$ & $0.04 \pm 0.00^{\mathrm{e}}$ & $0.01 \pm 0.00^{\mathrm{e}, \mathrm{f}}$ \\
\hline
\end{tabular}

Data is expressed as mean $\pm \mathrm{SEM}, \mathrm{n}=9$. Within a row mean values superscripted with different letters are significantly different $(\mathrm{p}<0.05)$. The letters $\mathrm{K}, \mathrm{SP}, \mathrm{AN}, \mathrm{AM}$ and $\mathrm{S}$ display lactic acid bacteria isolated from banana varieties kolikuttu, seeni parakum, ambul nadee, ambun and seeni, respectively.

\section{Antibiotic susceptibility of lactic acid bacteria}

LAB isolates demonstrated significant differences $(\mathrm{p}<0.05)$ in susceptibility/resistance at tested antibiotic concentrations. Isolates K08 and SP26 were susceptible to all the antibiotics at tested concentrations (Table 10). Isolate AN18 was susceptible to all the antibiotics at tested concentrations except chloramphenicol at $30 \mu \mathrm{gmL}^{-1}$ concentration. Resistance or susceptibility to antibiotics alone will not cause risk in probiotic LAB candidates. Their ability to transfer the respective antibiotic resistance encoding genes is the real cause of risk (Gueimonde et al., 2013) and therefore there is a need to investigate prior to commercial applications.

\section{Auto aggregation ability of lactic acid bacteria}

Probiotics that are able to auto-aggregate have the potential to adhere into the gut epithelium. Therefore, aggregation is considered as a prerequisite of an ideal probiotic candidate (Kos et al., 2003). In this study, isolate K08 (E. durans) demonstrated highest autoaggregation of $76.5 \%$, which is higher than that reported by previous authors. Jeevaratnam and Nallala (2017) reported $53 \%$ auto-aggregation in E. durans at the end of 5 hour incubation. Significant differences $(p<0.05)$ in auto-aggregation were observed among the LAB strains (Table 11). Auto-aggregating ability of the LAB strains was observed to be time dependent and therefore, 
Table 10: Antibiotic susceptibility/resistance pattern of isolated lactic acid bacteria

\begin{tabular}{llcc}
\hline LAB isolates & \multicolumn{3}{l}{ Diameter (in mm) of the inhibition zone of the LAB strains } \\
& K08 & SP26 & AN18 \\
\hline & & & \\
Cefotaxime & $19.00 \pm 0.0^{\mathrm{b}}$ & $18.75 \pm 0.25^{\mathrm{b}}$ & $20.00 \pm 0.0^{\mathrm{b}}$ \\
Gentamycin & $15.25 \pm 0.25^{\mathrm{c}}$ & $19.00 \pm 0.71^{\mathrm{a}}$ & $16.00 \pm 0.0^{\mathrm{b}, \mathrm{c}}$ \\
Tetracycline & $26.75 \pm 0.25^{\mathrm{a}}$ & $11.00 \pm 0.41^{\mathrm{c}}$ & $11.00 \pm 0.0^{\mathrm{c}}$ \\
Chloramphenicol & $17.75 \pm 0.25^{\mathrm{b}}$ & $21.00 \pm 0.71^{\mathrm{a}}$ & $0.0 \pm 0.0^{\mathrm{c}}$ \\
Sulphamethoxazole & $12.50 \pm 0.96^{\mathrm{c}}$ & $14.00 \pm 0.0^{\mathrm{c}}$ & $27.00 \pm 0.71^{\mathrm{a}}$ \\
Ciprofloxacin & $18.50 \pm 0.29^{\mathrm{b}}$ & $14.75 \pm 0.63^{\mathrm{c}}$ & $21.50 \pm 0.50^{\mathrm{b}}$ \\
Amikacin & $19.00 \pm 0.0^{\mathrm{d}}$ & $19.25 \pm 0.25^{\mathrm{c}, \mathrm{d}}$ & $21.00 \pm 0.71^{\mathrm{c}}$ \\
Bacitracin & $10.00 \pm 0.91^{\mathrm{f}}$ & $22.75 \pm 0.25^{\mathrm{c}}$ & $31.25 \pm 0.95^{\mathrm{g}}$ \\
Ampicillin & $27.00 \pm 0.0^{\mathrm{a}}$ & $11.25 \pm 0.75^{\mathrm{c}}$ & $17.25 \pm 0.48^{\mathrm{b}}$ \\
Amoxicillin & $27.50 \pm 0.50^{\mathrm{a}}$ & $12.00 \pm 0.0^{\mathrm{c}, \mathrm{d}}$ & $11.00 \pm 0.0^{\mathrm{d}}$ \\
Cephalothin & $21.50 \pm 0.29^{\mathrm{b}, \mathrm{c}}$ & $22.00 \pm 0.8^{\mathrm{c}}$ & $20.25 \pm 0.75^{\mathrm{b}, \mathrm{c}}$ \\
Vancomycin & $24.50 \pm 0.50^{\mathrm{a}}$ & $23.00 \pm 0.0^{\mathrm{a}}$ & $12.00 \pm 0.0^{\mathrm{b}}$ \\
Erythromycin & $18.75 \pm 0.25^{\mathrm{c}}$ & $16.75 \pm 0.75^{\mathrm{d}}$ & $11.50 \pm 0.29^{\mathrm{e}}$ \\
Control & $0 \pm 0^{\mathrm{a}}$ & $0 \pm 0^{\mathrm{a}}$ & $0 \pm 0^{\mathrm{a}}$ \\
\hline
\end{tabular}

Data is expressed as mean \pm SEM, $n=9$. Within a row mean values superscripted with different letters are significantly different $(\mathrm{p}<0.05)$. The letters K, SP and AN display lactic acid bacteria isolated from banana varieties kolikuttu, seeni parakum and ambul nadee, respectively. Control - no antibiotic. Cefotaxime-15 $\mu \mathrm{g}$; gentamycin-10 $\mu \mathrm{g}$; tetracycline-30 $\mu \mathrm{g}$; chloramphenicol-30 $\mu \mathrm{g}$; sulphamethoxazole- $25 \mu \mathrm{g}$; ciprofloxacin-5 $\mu \mathrm{g}$; amikacin-30 $\mu \mathrm{g}$; bacitracin-10 units; ampicillin- $10 \mu \mathrm{g}$; amoxicillin-30 $\mu \mathrm{g}$; cephalothin-30 $\mu \mathrm{g}$; vancomycin-30 $\mu \mathrm{g}$; erythromycin-30 $\mu \mathrm{g}$.

Table 11: Auto-aggregation percentage of isolated lactic acid bacteria with time

\begin{tabular}{lccccc}
\hline LAB isolates & \multicolumn{5}{c}{ Auto-aggregation percentage of LAB with time (hours) } \\
& $1 \mathrm{~h}$ & $2 \mathrm{~h}$ & $3 \mathrm{~h}$ & $4 \mathrm{~h}$ & $5 \mathrm{~h}$ \\
\hline \multirow{2}{*}{ K08 } & $21.33 \pm 0.65^{\mathrm{a}}$ & $31.66 \pm 0.74^{\mathrm{a}}$ & $37.12 \pm 1.28^{\mathrm{a}}$ & $42.01 \pm 0.87^{\mathrm{b}}$ & $76.53 \pm 0.59^{\mathrm{a}}$ \\
SP26 & $2.63 \pm 0.17^{\mathrm{d}, \mathrm{e}}$ & $7.04 \pm 0.30^{\mathrm{d}}$ & $10.45 \pm 0.32^{\mathrm{d}, \mathrm{e}}$ & $45.53 \pm 0.55^{\mathrm{a}}$ & $61.10 \pm 1.19^{\mathrm{c}}$ \\
AN18 & $4.45 \pm 0.39^{\mathrm{c}}$ & $7.00 \pm 0.54^{\mathrm{d}}$ & $11.97 \pm 0.49^{\mathrm{d}}$ & $22.32 \pm 0.70^{\mathrm{f}}$ & $38.51 \pm 1.02^{\mathrm{e}}$ \\
\hline
\end{tabular}

Data is expressed as mean $\pm \mathrm{SEM}, \mathrm{n}=9$. Within a column mean values superscripted with different letters are significantly different $(\mathrm{p}<0.05)$. The letters $\mathrm{K}$, SP and AN display lactic acid bacteria isolated from banana varieties kolikuttu, seeni parakum and ambul nadee, respectively.

increment of auto-aggregation was observed with the increase of incubation period.

\section{Hydrophobicity of lactic acid bacteria}

Probiotics should exhibit hydrophobic surfaces for better adherence to cells and solid materials in the gut (Del-Re et al., 2000). Results revealed that isolates K08 (E. durans) and SP26 (E. faecium) demonstrated $69.9 \%$ and $60.2 \%$ affinity to xylene respectively. Therefore these strains have elevated hydrophobic properties (Giarous et al., 2009). Further, it was observed that these strains demonstrated the highest auto-aggregation ability. Del-Re et al. (2000) suggested that hydrophobicity improves the auto-aggregation and observations of this study completely agree with the statement. Isolate AN18 (L. curieae) demonstrated $67.4 \pm 0.2 \%$ affinity to ethyl acetate, which is a basic solvent and electron donor (Figure 2). 


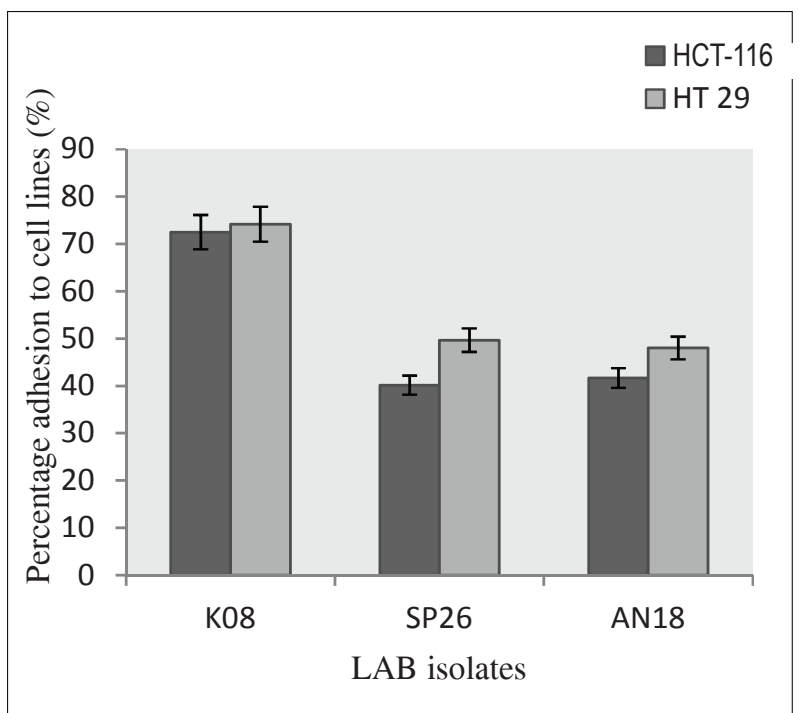

Figure 2: Hydrophobicity of LAB isolates

Data is expressed as mean \pm SEM, $n=9$. The letters $K$, SP and AN display lactic acid bacteria isolated from banana varieties kolikuttu, seeni parakum and ambul nadee.

\section{Adhesion to epithelial cell lines by lactic acid bacteria}

Significant differences $(p<0.05)$ in adhesion of LAB strains to HCT-116 and HT-29 cell lines were observed. The results revealed that isolate $\mathrm{KO} 8$ (E. durans) exhibited the highest cell adhesion, with HCT-116 as well as HT-29 demonstrating $72.5 \pm 5.9 \%$ and $74.2 \pm 4.9 \%$, respectively. The lowest cell adhesion was observed in isolate AN18 (L. curieae) that demonstrated $11.7 \pm 2.2 \%$ and $11.5 \pm 1.7 \%$ with HCT-116 and HT-29, respectively. Results of this study completely agree with Reid et al. (1988) on the relationship of auto-aggregation and cell adhesion (Figure 3).

\section{CONCLUSION}

In this study, three LAB strains E. durans (MF405179.1), E. faecium (MF574466.1) and L. curieae (MF405178.1) isolated from banana var. kolikuttu, seeni parakum and ambul nadee respectively, exhibited superior probiotic characteristics. Isolates $\mathrm{K} 08$ (E. durans) and SP26 (E. faecium) demonstrated superior hydrophobic properties and auto aggregative properties, which enable them to exhibit cell adhesion. Therefore, the present study provides evidence on the potential application of banana flour as an ideal substrate to produce nondairy probiotic food. It is recommended to investigate the compatibility of banana flour in novel non-dairy food formulations including banana flour incorporated

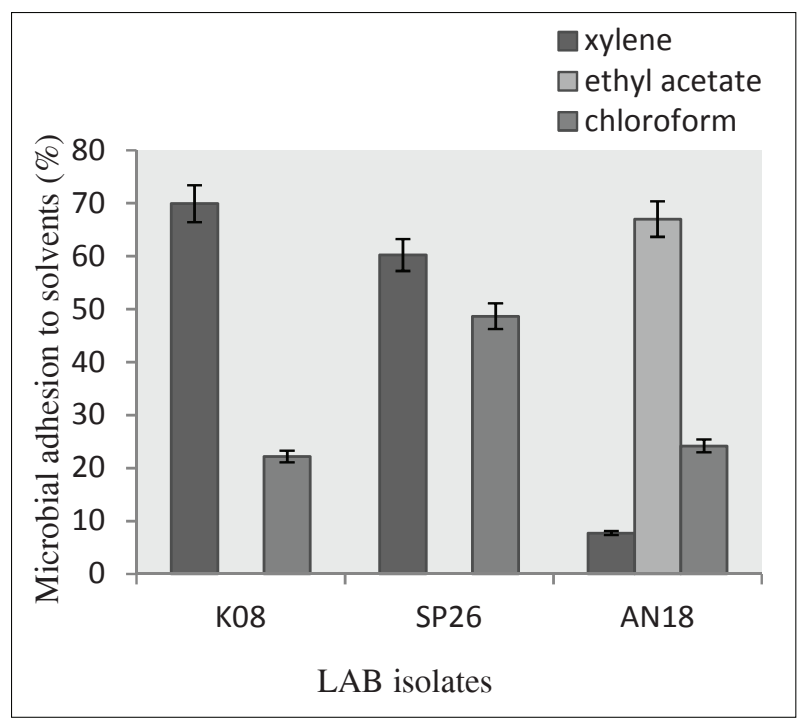

Figure 3: Cell adhesions of LAB isolates

Data is expressed as mean \pm SEM, $n=9$. The letters $K$, SP and $\mathrm{AN}$ display lactic acid bacteria isolated from banana varieties kolikuttu, seeni parakum and ambul nadee.

supplements/preparations, non-dairy yoghurts, drinks including frizzy drinks and confectionaries that can be developed into commercial products.

\section{Acknowledgement}

Authors acknowledge the Indo-Sri Lanka InterGovernmental Science and Technology Cooperation Programme for providing the financial assistance for this study and NAM S\&T Centre for awarding joint NAM-ICCBS post-graduate fellowship to D.M.W.D. Divisekera.

\section{REFERENCES}

Altschul S.F., Gish W., Miller W., Myers E.W. \& Lipman D.J. (1990). Basic local alignment search tool. Journal of Molecular Biology 215(3): 403-410.

DOI: https://doi.org/10.1016/S0022-2836(05)80360-2

Alves L.A.A.S., Lorenzo J.A., Gonçalves C.A.A., Santos B.A., Heck R.T., Cichoski A.J. \& Campagnol P.C.B. (2016). Production of healthier bologna type sausages using pork skin and green banana flour as fat replacers. Meat Science 121: $73-78$.

DOI: https://doi.org/10.1016/j.meatsci.2016.06.001

Aswathy R.G., Ismail B., John R.P. \& Nampoothiri K.M. (2008). Evaluation of the probiotic characteristics of newly isolated lactic acid bacteria. Applied Biochemistry and Biotechnology 151(2-3): 244-255.

DOI: https://doi.org/10.1007/s12010-008-8183-6 
Bakari D., Tatsadjieu N.L., Mbawala A. \& Mbofung C.M. (2011). Assessment of physiological properties of some lactic acid bacteria isolated from the intestine of chickens used as probiotics and antimicrobial agents against enteropathogenic bacteria. Innovative Romanian Food Biotechnology 8: 33-40.

Batista A.L.D. et al. (15 authors) (2017). Developing a synbiotic fermented milk using probiotic bacteria and organic green banana flour. Journal of Functional Foods 38: 242-250. DOI: https://doi.org/10.1016/j.jff.2017.09.037

Chmielewska A. \& Szajewska H. (2010). Systematic review of randomised controlled trials: probiotics for functional constipation. World Journal of Gastroenterology 16(1): 69-75.

Chowdhury A., Hossain M.N., Mostazir N.J., Fakruddin M., Billah M.M. \& Ahmed M.M. (2012). Screening of Lactobacillus spp. from buffalo yoghurt for probiotic and antibacterial activity. Journal of Bacteriology and Parasitology 3:156.

DOI: https://doi.org/10.4172/2155-9597.1000156

Clinical and Laboratory Standards Institute (CLSI) (2012). Performance Standards for Antimicrobial Susceptibility Tenting; Twenty Second Informational Supplement. Available at http://www.facm.ucl.ac.be/intranet/CLSI/ CLSI-2017-M100-S27.pdf. Accessed 12 June 2015.

Collee J.C., Fraser A.G., Marmion B.P. \& Simmons A. (2006). Mackie and MaCartney Practical Medical Microbiology, $14^{\text {th }}$ edition, pp. 131-140. Church Hill Livingstone, London, UK.

Del-Re B., Sgorbati B., Miglioli M. \& Palenzona D. (2000). Adhesion, autoaggregation and hydrophobicity of 13 strains of Bifidobacterium longum. Letters in Applied Microbiology 31(6): 438-442. DOI: https://doi.org/10.1046/j.1365-2672.2000.00845.x

De Man J.C., Rogosa M. \& Sharpe M.E. (1960). A medium for the cultivation of lactobacilli. Journal of Applied Bacteriology 23(1): 130-135. DOI: https://doi.org/10.1111/j.1365-2672.1960.tb00188.x

Doi K., Phuong O., Kawatou F., Nagayoshi Y., Fujino Y. \& Ohshima T. (2013). Identification and characterisation of lactic acid bacteria isolated from fermented rice bran product. Springer Plus 2: 485. DOI: https://doi.org/10.1186/2193-1801-2-485

Duary R.K., Rajput Y.S., Batish V.K. \& Grover S. (2011). Assessing the adhesion of putative indigenous probiotic lactobacilli to human colonic epithelial cells. Indian Journal of Medical Research 134(5): 664-671. DOI: https://doi.org/10.4103/0971-5916.90992

Dunne C. et al. (14 authors) (2001). In vitro selection criteria for the probiotic bacteria of human origin: correlate with the vivo findings. American Journal of Clinical Nutrition 73(2 Suppl): 386-392.

DOI: https://doi.org/10.1093/ajen/73.2.386s

Ekanayaka E.M.D.S.N.E., Samarasinghe W.L.G. \& Randeni R.A.V.K. (2011). An unrecorded banana cultivar from Sri Lanka. Annals of the Sri Lanka Department of Agriculture 3: 37-42.
Felley C.P., Corthesy-Theulaz I., Rivero J.L., Sipponene P., Kaufmann B.P., Wiesel P.H., Brassart D., Pfeifer A., Blum A.L. \& Michetti P. (2001). Favourable effect of acidified milk (LC-1) on Helicobacter gastritis in man. European Journal of Gastroenterology \& Hepatology 13(1): 25-29. DOI: https://doi.org/10.1097/00042737-200101000-00005

Food and Agriculture Organization (FAO) (2007). FAO Technical Meeting on Prebiotics: Food Quality and Standards Service (AGNS). Food and Agriculture Organization of the United Nations, Rome, Italy.

Giaouris E., Chapot-Chartier M. \& Briandet R. (2009). Surface physicochemical analysis of natural Lactococcus lactis strains reveals the existence of hydrophobic and low charged strains with altered adhesive properties. International Journal of Food Microbiology 131(1): 2-9. DOI: https://doi.org/10.1016/j.ijfoodmicro.2008.09.006

Gibson G.R. \& Fuller R. (2000). Aspects of in vitro and in vivo research approaches directed toward identifying probiotics and prebiotics for human use. Journal of Nutrition 130(2S suppl): 391-395.

Gomes A.A.B., Ferreira M.E. \& Pimentel T.C. (2016). Bread with flour obtained from green banana with its peel as partial substitute for wheat flour: physical, chemical and microbiological characteristics and acceptance. International Food Research Journal 23(5): 2214-2222.

Gueimonde M., Sanchez B., Reyes-Gavilan G.L.C. \& Margolles A. (2013). Antibiotic resistance in probiotic bacteria. Frontiers in Microbiology 4: 202.

DOI: https://doi.org/10.3389/fmicb.2013.00202

Guglielmetti S., Mora D., Gschwender M. \& Popp K. (2011). Randomised clinical trial: Bifidobacterium bifidum MIMBb75 significantly alleviates irritable bowel syndrome and improves quality of life: a double-blind, placebo-controlled study. Alimentary Pharmacology and Therapeutics 33(10): 1123-1132.

DOI: https://doi.org/10.1111/j.1365-2036.2011.04633.x

Gupta H. \& Malik R.K. (2007). Incidence of virulence in bacteriocin producing enterococcal isolates. Dairy Science and Technology 87: 587-601. DOI: https://doi.org/10.1051/lait:2007031

Halder D., Mandal M., Chatterjee S.S., Pal N.K. \& Mandal S. (2017). Indigenous probiotic Lactobacillus isolates presenting antibiotic like activity against human pathogenic bacteria. Biomedicines 5(2): E31.

Homayouni A., Alizadeh M., Alikhah H. \& Zijah V. (2012). Functional dairy probiotic food development: trends, concepts, and products. Immunology and Microbiology. IntechOpen, Available at https://www.intechopen. com/books/probiotics/functional-dairy-probiotic-fooddevelopment-trends-concepts-and-products

Ibourahema C., Dauphin R.D., Jacqueline D. \& Thonart P. (2008). Characterisation of lactic acid bacteria isolated from poultry farms in Senegal. African Journal of Biotechnology 7(12): 2006-2012. DOI: https://doi.org/10.5897/AJB2008.000-5048

Jeevaratnam K. \& Nallala V. (2017). Probiotic evaluation of Enterococcus durans VJI19 isolated from gastrointestinal 
tract of broiler chicken. International Journal of Advanced Life Sciences 10(1): 139-155.

Kechagia M., Basoulis D., Konstantopoulou S., Dimitriadi D., Gyftopoulou K., Skarmoutsou N. \& Fakiri E.M. (2013). Health benefits of probiotics: a review. ISRN Nutrition 2013: Article ID 481651.

DOI: https://doi.org/10.5402/2013/481651

Kimura H. (2014). Production and physiological effects of hydrogen sulfide. Antioxidants and Redox Signaling 20(5): 783-793.

DOI: https://doi.org/10.1089/ars.2013.5309

Kos B., Suskovic J., Vukovic S., Simpraga M., Frece J. \& Matosic S. (2003). Adhesion and aggregation ability of probiotic strain Lactobacillus acidophilus M92. Journal of Applied Microbiology 94(6): 981-987.

DOI: https://doi.org/10.1046/j.1365-2672.2003.01915.x

Kumar V.B., Vijayendra S.V.N. \& Reddy O.V.S. (2015). Trends in dairy and non-dairy probiotic products - a review. Journal of Food Science and Technology 52(10): 6112-6124. DOI: https://doi.org/10.1007/s13197-015-1795-2

Kunchala R., Banerjee R., Datta Mazumdar S.D., Durgalla P., Srinivas V. \& Gopalakrishnan S. (2016). Characterisation of potential probiotic bacteria isolated from sorghum and pearl millet of the semi-arid tropics. African Journal of Biotechnology 15(16): 613-621.

DOI: https://doi.org/10.5897/AJB2016.15212

Langston C.W. \& Bouma C. (1960). A study of the microorganisms from grass silage. Journal of Applied Microbiology 8(4): 223-234.

Menconi A., Morgan M.J., Pumford N.R., Hargis B.M. \& Tellez G. (2013). Physiological properties and Salmonella growth inhibition of probiotic Bacillus strains isolated from environmental and poultry sources. International Journal of Bacteriology 2013: Article ID 958408

DOI: https://doi.org/10.1155/2013/958408

Menconi A., Kallapura G., Latorre J.D., Morgan M.J., Pumford N.R., Hargis B.M. \& Tellez G. (2014). Identification and characterisation of lactic acid bacteria in a commercial probiotic culture. Bioscience of Microbiota, Food and Health 33(1): 25-30.

DOI: https://doi.org/10.12938/bmfh.33.25

Mora D. \& Arioli S. (2014). Microbial urease in health and disease. PLOS Pathogens 10(12): Article ID e1004472. DOI: https://doi.org/10.1371/journal.ppat.1004472

Nazari H., Khanjanzadeh A. \& Rezvani F. (2012). Characterisation of lactic acid bacteria as a probiotic. Canadian Journal on Medicine 3(3): 49-55.

Pessione E. \& Cirrincione S. (2016). Bioactive molecules released in food by lactic acid bacteria: encrypted peptides and biogenic amines. Frontiers in Microbiology 7: 876. DOI: https://doi.org/10.3389/fmicb.2016.00876

Pyar H. \& Peh K.K. (2014). Characterisation and identification of Lactobacillus acidophilus using biolog rapid identification system. International Journal of Pharmacy and Pharmaceutical Sciences 6(1): 189-193.

Rayo L.M., Carvalho L.C., Sarda F.A.H., Dacanal G.C., Menezes E.W. \& Tadini C.C. (2015). Production of instant green banana flour (Musa cavendischii, var. Nanicao) by a pulsed-fluidized bed agglomeration. LWT-Food Science and Technology 63(1): 461-469.

DOI: https://doi.org/10.1016/j.lwt.2015.03.059

Reid G., McGroarty J.A., Angotti R. \& Cook R.L. (1988). Lactobacillus inhibitor production against Escherichia coli and coaggregation ability with uropathogens. Canadian Journal of Microbiology 34(3): 344-351.

DOI: https://doi.org/10.1139/m88-063

Reis N.A., Saraiva M.A.F., Duarte E.A.A., de Carvalho E.A., Vieira B.B. \& Evangelista-Barreto N.S. (2016). Probiotic properties of lactic acid bacteria isolated from human milk. Journal of Applied Microbiology 121(3): 811-820. DOI: https://doi.org/10.1111/jam.13173

RnR Market Research (2017). Probiotics Market to Grow at 7\% CAGR to 2022 Driven by Demand for Probiotic Dietary Supplements. Available at https://www.prnewswire. com/news-releases/probiotics-market-to-grow-at-7cagr-to-2022-driven-by-demand-for-probiotic-dietarysupplements-648651313.html. Accessed 15 January 2018.

Saitou N. \& Nei M. (1987). The neighbor-joining method: a new method for reconstructing phylogenetic trees. Molecular Biology and Evolution 4(4): 406-425.

Segundo C., Roman L., Gomez M. \& Martínez M.M. (2017). Mechanically fractionated flour isolated from green bananas ( $M$. cavendishiivar. nanica) as a tool to increase the dietary fiber and phytochemical bioactivity of layer and sponge cakes. Food Chemistry 219: 240-248. DOI: https://doi.org/10.1016/j.foodchem.2016.09.143

Shahriar M., Rashidul M.H., Kabir S., Dewan I. \& Bhuyian M.A. (2011). Effect of proteinase-K on genomic DNA extraction from Gram-positive strains. Stamford Journal of Pharmaceutical Sciences 4(1): 53-57.

DOI: https://doi.org/10.3329/sjps.v4i1.8867

Sharma M. \& Shukla G. (2016). Metabiotics: one step ahead of probiotics; an insight into mechanisms involved in anticancerous effect in colorectal cancer. Frontiers in Microbiology 7: 1940.

DOI: https://doi.org/10.3389/fmicb.2016.01940

Sharma S., Arora M. \& Baldi A. (2013). Probiotics in India: current status and future prospects. Pharm Aspire 4(1): Available at https://www.researchgate.net/profile/ Dr_Ashish_Baldi/publication 1257537041_Probiotics_ in_India_Current_status_and_future_prospects/ links/0c960525661ad870f0000000.pdf.

Shewale R.N., Sawale P.D., Khedkar C.D \& Singh A. (2014). Selection criteria for probiotics: a review. International Journal of Probiotics and Prebiotics 9(1): 17-22.

Topping D.L. \& Clifton P.M. (2001). Short-chain fatty acids and human colonic function: roles of resistant starch and nonstarch polysaccharides. Physiological Reviews 81(3): 1031-1064.

DOI: https://doi.org/10.1152/physrev.2001.81.3.1031

Vicente J.L., Torres-Rodriguez A., Higgins S.E., Pixley C., Tellez G., Donoghue A.M. \& Hargis B.M. (2008). Effect of a selected Lactobacillus spp-based probiotic on Salmonella enteritidis-infected broiler chicks. Avian Diseases 52(1): 143-146.

DOI: https://doi.org/10.1637/7847-011107-ResNote 
Working Group Report on Drafting Guidelines for the Evaluation of Probiotics in Food (2002). Joint FAO/ WHO, Ontario, Canada. Available at http://www.who.int/ foodsafety/fs_management/en/probiotic_guidelines.pdf. Accessed 18 February 2018.
Yadav R., Puniya A. K. \& Shukla P. (2016). Probiotic properties of Lactobacillus plantarum RYPR1 from an indigenous fermented beverage Raabadi. Frontiers in Microbiology 7:1683.

DOI: https://doi.org/10.3389/fmicb.2016.01683 